Journal of Maternal and Child Health (2018), 3(3): 216-224

https://doi.org/10.26911/thejmch.2018.03.03.06

\title{
Path Analysis on the Determinants of Unwanted Pregnancy Among Adolescents in Madiun, East Java
}

\author{
Bunga Mutiara'), Uki Retno Budihastuti²), Eti Poncorini Pamungkasari3) \\ 1)Masters Program in Public Health, Universitas Sebelas Maret \\ 2)Department of Obstetrics and Ginecology, Dr. Moewardi Hospital, Surakarta \\ 3)Faculty of Medicine, Universitas Sebelas Maret
}

\begin{abstract}
Background: Unintended pregnancy is a worldwide problem that affects women, their families, and society. Unintended pregnancy can result from early marriage, contraceptive failure, non-use of contraceptive services, and, less commonly, rape. Consequences of unintended pregnancy include abortion with its long-term negative health effects including infertility and maternal death. This study aimed to examine the determinants of unwanted pregnancy among adolescents in Madiun, East Java, using path analysis model.

Subjects and Method: This was a case control study conducted in Madiun, East Java, from April 4 to May 14, 2018. A sample of 150 adolescents was selected by fixed disease sampling, comprising 30 adolescents with and 120 adolescents without unwanted pregnancy. The dependent variable was unwanted pregnancy. The independent variables were knowledge, attitude, religiosity, sexual behavior, media exposure, parental role, and peer role. The data were collected by questionnaire and analyzed by path analysis run on Stata 13.

Results: Unwanted pregnancy was directly determined by negative sexual behavior $(b=4.14 ; 95 \%$ $\mathrm{CI}=2.83$ to $5.45 ; \mathrm{p}<0.001)$. It was indirectly determined by negative peer role, negative media exposure, negative attitude, parental role, better knowledge, and religiosity.

Conclusion: Unwanted pregnancy is directly determined by negative sexual behavior. It is indirectly determined by negative peer role, negative media exposure, negative attitude, parental role, better knowledge, and religiosity
\end{abstract}

Keywords: unwanted pregnancy, determinants, adolescents, path analysis

\section{Correspondence:}

Bunga Mutiara, Masters Program in Public Health, Universitas Sebelas Maret, Jl. Ir. Sutami 36 A, Surakarta 57126, Central Java. Email: theoo3theo@gmail.com

\section{BACKGROUND}

Landry et al. (2017); Unicef (2016); WHO (2017a) defines teenagers as someone between the ages of 10-19. The adolescent phase is a transition from the childhood phase to the adult phase both physically and psychologically. Therefore, a safe, healthy and productive process in transition is very important.

WHO (2017a) and WHO (2017b) describes that teenagers around the world facing quite a number of challenges related to their sexual and reproductive health, including lack of education and information about unwanted pregnancies, lack of access to health services especially for contraception and safe abortion and risk of sexually transmitted infections.

Darroch et al., (2016); Woog V et al., (2017) mentions that pregnancies among 15-19 year old girls in developing countries by 2016 amounted to 21 million. At least, more than a third of young mothers are born from 15 developing countries are unplanned (43\% in Asia, 45\% in Africa and $74 \%$ in Latin America and the Caribbean).

Health Research and Development office, (2013) reported that there are pregnancies in adolescents aged 15-19 years of 
1.97\%. Pranata et al. (2012) also mentioned that the unplanned pregnancy rate in East Java was $12.2 \%$.

WHO (2018) describes that teenage pregnancy is at risk of maternal death. Exavery et al., (2014); WHO, (2018); Darroch et al. (2016) mention that about half of teenage pregnancies aged 15-19 years in developing countries end up with unsafe abortions.

Health Research and Development Office, (2013); Exavery et al., (2014); WHO, (2018) present higher rates of neonatal, infant and under-five mortality in young mothers who are mothers who deliver at the age under 20 years than those aged 2029 years.

\section{SUBJECTS AND METHOD}

\section{Study Design}

This was a case control study conducted in Madiun District, East Java, from April 4 to May 14, 2018.

\section{Population and Sample}

The target population in the study was all adolescents aged 10-19 years with unwanted pregnancies and desirable pregnancies in Madiun District. A sample of 150 study subjects was selected by fixed disease sampling.

\section{Study Variables}

The dependent variable was unwanted pregnancy in adolescent, while the independent variables werethe determinant of parental role, peer role, religiusity, the access of porn media, knowledge, attitude, and sexual behavior.

\section{Operational Definition of Variables}

The operational definition of unwanted pregnancy variables was a pregnancy that occurs outside the plan whether physically or psychologically the couple is unprepared and/or does not want a pregnancy incident. The measurement scale was categorical, coded o for no and 1 for yes.
Parental role was defined as the participation, involvement, behavior and supervision of parents with or the children whether it is at home, school and everything related to the future of the child. It was measured by questionnaire. The measurement scale was continuous, but for the purpose data analysis, it was transformed into dichotomous, coded o for weak and 1 for strong.

Peer role was defined as a group of individual who have the same aspects as age, feeling, level of development and experience. It was measured by questionnaire. The measurement scale was continuous, but for the purpose data analysis, it was transformed into dichotomous, coded o for weak and 1 for strong.

Access to porn media was defined as a site that provides sexual information in the form of video or audio. It was measured by questionnaire. The measurement scale was continuous, but for the purpose data analysis, it was transformed into dichotomous, coded o for low and 1 for high.

Religiosity was defined as the values in a person including the level of knowledge, beliefs and religious beliefs and then the actualization in everyday life. It was measured by questionnaire. The measurement scale was continuous, but for the purpose data analysis, it was transformed into dichotomous, coded o for low and 1 for high.

Knowledge was defined as all that teenagers know about reproductive and sexual health. It was measured by questionnaire. The measurement scale was continuous, but for the purpose data analysis, it was transformed into dichotomous, coded o for low and 1 for high.

Attitude was defined as adolescent behavior, thought, feeling, and belief in responding to an incentive or a problem encountered. It was measured by question- 
naire. The measurement scale was continuous, but for the purpose data analysis, it was transformed into dichotomous, coded $\mathrm{o}$ for negative and 1 for positive.

Sexual behavior was defined as the behavior involving physical touch between men and women who have reached the stage of intercourse. It was measured by questionnaire. The measurement scale was continuous, but for the purpose data analysis, it was transformed into dichotomous, coded o for no and 1 for yes.

\section{Data Instrument}

Data on unwanted pregnancy obtained from Madiun District Religious Office. The other variables were measured by questionnaire. The questionnaires were frst tested for its validity and reliability before distributed. The reliability test was performed on 30 respondents and using SPSS 13 program to calculate alpha Cronbach.

\section{Data Analysis}

Data analysis techniques used were univariate, bivariate, and multivariate analyzes. Univariate analysis aims to explain each characteristic data. Bivariate analysis aims to analyze the relationship of two variables using SPSS with chi square test. Path analysis model was run on Stata 13 program.

\section{Research Ethics}

The research ethics of this study included informed consent, anonymity, confidentiality and ethical clearance that have been obtained from ethical committees of Moewardi hospital, Surakarta, Central Java with Number: 375 / III / HREC / 2018.

\section{RESULTS}

\section{Univariate Analysis}

Table 1 shows that adolescents who received strong parental roles were 108 (72\%) and weak (42\%).

Adolescents with negative peer role amounted to $41(27.3 \%)$ and the positive one were $109(72.7 \%)$. Adolescents with high religiosity were $106(70.7 \%)$ and those with low religiosity were 44 (29.3\%).

Table 1. Univariate analysis

\begin{tabular}{lll}
\hline Variables & \multicolumn{1}{c}{ n } & \% \\
\hline Pregnancy Status & & \\
Normal & 120 & 80 \\
Premature rupture of & 30 & 20 \\
membrane & & \\
$\begin{array}{l}\text { Parental role } \\
\text { Strong }\end{array}$ & 108 & 72 \\
Weak & 42 & 28 \\
Peer role & & \\
Yes & 41 & 27.3 \\
No & 109 & 72.7 \\
Religiousity & & \\
High & 106 & 70.7 \\
Low & 44 & 29.3 \\
Access to porn & & \\
Yes & 43 & 28.7 \\
No & 107 & 71.3 \\
Knowledge & & \\
High & 101 & 67.3 \\
Low & 49 & 32.7 \\
Attitude & & \\
Positive & 106 & 70.7 \\
Negative & 44 & 29.3 \\
Sexual Behaviour & & \\
Negative & & \\
Positive & 42 & 28 \\
\hline
\end{tabular}

Teenagers who access porno media were (28.7\%) and those who do not were 107 (71.3\%). Adolescents with high knowledge of reproductive health were $101(67.3 \%)$ and those with low knowledge were 49 (32.7\%).

Adolescents with positive attitudes toward sexuality were 106 (70.7\%) and those with negative attitude were44 (29,3\%). Adolescents who had negative sexual behavior were $42(28 \%)$ and those with positive ones were 108 (72\%).

\section{Bivariate Analysis}

Table 2 shows the relationship of independent variables (sexual behavior, attitudes, knowledge, peer role, religiosity, parental role, access to porn media) to the dependent variable (unwanted pregnancy in adolescents) 
Table 2. Bivariate analysis influence of independent variables with unwanted pregnancy in adolescents

\begin{tabular}{|c|c|c|c|c|c|c|c|c|c|}
\hline \multirow[b]{2}{*}{ Variable } & \multicolumn{2}{|c|}{ KD } & \multicolumn{2}{|c|}{ KTD } & \multicolumn{2}{|c|}{ Total } & \multirow[b]{2}{*}{ OR } & \multirow[b]{2}{*}{$95 \%$ CI } & \multirow[b]{2}{*}{$\mathbf{p}$} \\
\hline & $\begin{array}{c}n= \\
120\end{array}$ & $\%$ & $\mathbf{n}=\mathbf{3 0}$ & $\%$ & $\begin{array}{c}n= \\
150\end{array}$ & $\%$ & & & \\
\hline \multicolumn{10}{|l|}{ Parental role } \\
\hline Strong & 103 & 85.8 & 5 & 16.7 & 108 & 100 & 0.33 & 0.01 to & $<0.001$ \\
\hline Weak & 17 & 14.2 & 25 & 83.3 & 42 & 100 & & 0.10 & \\
\hline \multicolumn{10}{|l|}{ Peer roles } \\
\hline Negative & 14 & 11.7 & 27 & 90 & 41 & 100 & 68.1 & 18.2 to & $<0.001$ \\
\hline Positive & 106 & 88.3 & 3 & 10 & 109 & 100 & & 254 & \\
\hline Religiousity & & & & & & & & & $<0.001$ \\
\hline High & 103 & 85.8 & 3 & 10 & 106 & 100 & 0.18 & 0.01 to & \\
\hline Low & 17 & 14.2 & 27 & 90 & 44 & 100 & & 0.07 & \\
\hline \multicolumn{10}{|l|}{ Access to porn } \\
\hline Yes & 19 & 15.8 & 24 & 80 & 43 & 100 & 21.2 & 7.66 to & $<0.001$ \\
\hline No & 101 & 84.2 & 6 & 20 & 107 & 100 & & 58.97 & \\
\hline Knowledge & & & & & & & & & $<0.001$ \\
\hline High & 98 & 81.7 & 3 & 10 & 101 & 100 & 0.25 & 0.01 & \\
\hline Low & 22 & 18.3 & 27 & 90 & 49 & 100 & & to 0.09 & \\
\hline Attitude & & & & & & & & & $<0.001$ \\
\hline Positive & 103 & 85.8 & 3 & 10 & 106 & 100 & 54.5 & 14.8 to & \\
\hline Negative & 17 & 14.2 & 27 & 90 & 44 & 100 & & 199.7 & \\
\hline Sexual Behaviour & & & & & & & & & $<0.001$ \\
\hline Negative & 15 & 12.5 & 27 & 90 & 42 & 100 & 63 & 17 to 233 & \\
\hline Positive & 105 & 87.5 & 3 & 10 & 108 & 100 & & & \\
\hline
\end{tabular}

\section{The results of path analysis}

Table 3 showed that there was a relationship between sexual behavior and unwanted pregnancy $(\mathrm{b}=4.14 ; 95 \% \mathrm{CI}=2.83$ to 5.45 ; $\mathrm{p}<0.001)$. Adolescents with negative sexual behavior had higher risk to unwanted pregnancy compared to adolescents who have positve sexual behavior.

There was a relationship between attitude and unwanted pregnancy $(b=5.59$; $95 \% \mathrm{CI}=7.08$ to $4.11 ; \mathrm{p}<0.001$ ). Adolescents with negative attitude were more likely to have negative sexual behaviors which lead to unwanted pregnancy than adolescents who have positive attitude.

There was a relationship between peer roles and attitude $(b=2.49 ; 95 \% \mathrm{CI}=0.32$ to 4.66; $\mathrm{p}=0.024)$. Adolescents with negative peer role were more likely to have negative attitude which lead to negative sexual behavior and increase the risk of unwanted pregnancy than positve peer role.
There was a relationship between peer role and knowledge $(b=1.87 ; 95 \% \mathrm{CI}=0.02$ to $3.72 ; \mathrm{p}=0.047$ ).

There was a relationship between religiosity and attitude $(b=2.32 ; 95 \% \mathrm{CI}=$ 0.31 to $4.34 ; \mathrm{p}=0.024)$. Adolescents with high religiosity level were more likely to had positive attitude.

There was a relationship between knowledge and attitude $(b=3.14 ; 95 \% \mathrm{CI}=$ 1.43 to $4.84 ; \mathrm{p}<0.001)$. Adolescents with higher knowledge were more likely to had positive attitude.

There was a relationship between access to porn media and knowledge ( $b=-$ 2.76; CI $95 \%=-4.28$ to $-1.25 ; \mathrm{p}<0.001$ ). Adolescent who accessed porn media would get basic informations about reproduction health without knowing the negative impact that would happen, therefore, adolescents with low level of knowledge were more likely to have negative attitude which lead to negative sexual behavior and increased the 
risk of unwanted pregnancy compared to those who did not access porn media.

There was a relationship between parents role and knowledge $(b=3.98 ; 95 \%$ $\mathrm{CI}=2.47$ to $5.49 ; \mathrm{p}<0.001)$. Adolescents with strong parents role would get adequate instructions, supervision, and education about reproduction health, and they were more likely to be protected from negative attitude which lead to negative sexual behavior and increased the risk of unwanted pregnancy compared to weak parents role.

There was a relationship between parental role and the level of religiosity $(b=$ $5.59 ; 95 \% \mathrm{CI}=4.11$ to $7.08 ; \mathrm{p}<0.001$ ). Adolescent with strong parental role would get religious education and they were more likely to be protected from negative attitude which lead to negative sexual behavior and the risk of unwanted pregnancy.

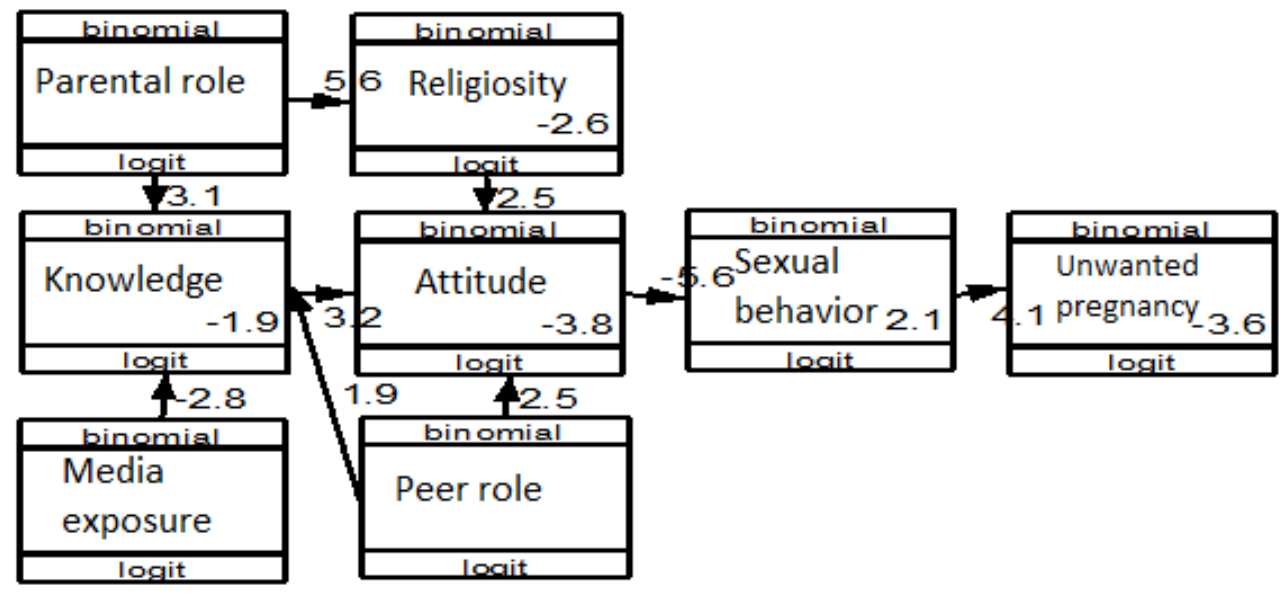

Figure 1. Structural model with estimation

Table 3. The Results of Path Analysis

\begin{tabular}{|c|c|c|c|c|c|c|}
\hline \multirow[b]{2}{*}{$\begin{array}{c}\text { Dependent } \\
\text { variable }\end{array}$} & & \multirow[b]{2}{*}{$\begin{array}{l}\text { Independent } \\
\text { variable }\end{array}$} & \multirow[b]{2}{*}{ b } & \multicolumn{2}{|c|}{ 95\% CI } & \multirow[b]{2}{*}{$\mathbf{p}$} \\
\hline & & & & $\begin{array}{l}\text { Lower } \\
\text { Limit }\end{array}$ & $\begin{array}{l}\text { Upper } \\
\text { Limit }\end{array}$ & \\
\hline Direct Effect & & & & & & \\
\hline $\begin{array}{l}\text { Unwanted pregnancy } \\
\text { Indirect Effect }\end{array}$ & $\leftarrow$ & Sexual Behavior & 4.14 & 2.83 & 5.45 & $<0.001$ \\
\hline Sexual Behavior & $\leftarrow$ & Attitude & 5.59 & 7.07 & 4.11 & $<0.001$ \\
\hline Attitude & $\leftarrow$ & Knowledge & 3.14 & 1.43 & 4.84 & $<0.001$ \\
\hline Attitude & $\leftarrow$ & Peer Role & 2.49 & 0.32 & 4.66 & 0.024 \\
\hline Attitude & $\leftarrow$ & Religiosity & 2.32 & 3.11 & $4 \cdot 34$ & 0.024 \\
\hline Knowledge & $\leftarrow$ & Parental Role & 3.13 & 1.41 & 4.86 & $<0.001$ \\
\hline Knowledge & $\leftarrow$ & Peer Role & 1.87 & 0.02 & 3.72 & 0.047 \\
\hline Knowledge & $\leftarrow$ & $\begin{array}{l}\text { Access to Porn } \\
\text { Media }\end{array}$ & -2.76 & -4.28 & -1.25 & $<0.001$ \\
\hline Religiosity & $\leftarrow$ & Parents Role & $5 \cdot 59$ & 4.11 & 7.07 & $<0.001$ \\
\hline
\end{tabular}

\section{DISCUSSION}

\section{The effect of parental role on} unwanted pregnancy

The result of analysis showed that there was a relationship between parental role and unwanted pregnancy in adolescents and it was statistically significant.

The result of this study was in line with a study by Ramadani et al. (2014), which stated that there wasa relationship between 
parents role and unwanted pregnancy in adolescents and it was statistically significant $(\mathrm{OR}=1.43 ; 95 \% \mathrm{CI}=1.23$ to $9.61 ; \mathrm{p}=$ 0.025). Lambani (2015); Oluwafemi (2017), also stated that girl adolescents were tend to get pregnant if they did not get the guidance and supervision from their parents. Many parents were busy with their careers so that their time was limited. Adolescents need direction and support to make good decisions on issues such as sex. If an adolescent cannot talk to his or her parents about sex either because they forbid sex or because they were not around, adolescents would come to their friends in order to find out about sex that lead to misinformation and the likelihood of pregnancy in adolescents was higher.

\section{The effect of peer role on unwant- ed pregnancy}

The result of analysis showed that there was a relationship between peer role and unwanted pregnancy.

The result of this study is consistent with a study by Azinar (2013), which stated that there was a relationship between permissive peer role and unwanted pregnancy in adolescent. Azinar (2013) and Mumah et al. (2014) stated that the effect of peers on unwanted pregnancies was probably because in the teenage stage, they would feel that the most comfortable place to share, communicate, and interact was to a friend than to his or her own parents. Therefore, the information and behavior of peers can be the cause or factor of unwanted pregnancy. During adolescence, adolescents would adjust to their peers.

\section{The effect of religiosity on un- wanted pregnancy}

The result of analysis showed that there was a relationship between religiosity and unwanted pregnancy in adolescent.

The result of this study was in line with a study by Azinar (2013), which stated that there was a relationship between religiosity and unwanted pregnancy and it was statistically significant. Azinar (2013); Mumah et al. (2014), stated that experts argued that there was a relationship between religion and premarital sex which was on deviant behavior. Religion established morale and belief in an individual so that it could became a good society. A person who lived his/her religion well would tend to behave according to the norms. Reza (2013); Aviyah and Farid, (2014) stated that the religious values were expected to control the adolescents selfcontrol and guide them to live physically and mentally healthy and also have healthy soul according to moral rules of their religion.

\section{The effect of negative media exposure on unwanted pregnancy}

The result of analysis showed that there was a relationship between negative media exposure and unwanted pregnancy in adolescent.

The result of this study was in line with the idea of Haidah et al. (2017), which stated that there wasa relationship between negative media exposure and unwanted pregnancy in adolescent and it was statistically significant. Azinar (2013); Cookingham and Ryan (2015); Alabi and Oni (2017) stated that adolescent who were exposed to social media that contain porn materials in it whether it was video, audio or message would tend to do sexual activity in the real life by two times. Access to porn media information could also lead to unwanted pregnancies, adolescents who were exposed to porn media without knowing the negative impact that would occur so that it encouraged them to conduct experiments by having sex at a very young age. 


\section{The effect of knowledge on un- wanted pregnancy}

The result of analysis showed that there was a relationship between knowledge and unwanted pregnancy in adolescent and it was statistically significant.

The result of this study was in line with a study by Ramadani et al. (2014), which stated that there was a relationship between knowledge and unwanted pregnancy in adolescents $(\mathrm{OR}=2.38$; $95 \% \mathrm{CI}=$ 1.16 to $5.29 ; \mathrm{p}=0.002)$. Saptarini and Suparmi (2016); WHO (2016) stated that knowledge can affect adolescent sexual behavioral. Therefore, to prevent and to ensure that adolescents were not affected by adverse reproductive health and sexual health, adequate knowledge of sexual and reproductive health was essential.

\section{The effect of attitude on unwanted pregnancy}

The result of analysis showed that there was a relationship between attitude and unwanted pregnancy in adolescent, and it was statistically significant.

The result of this study is consistent with a study by Azinar (2013), which stated that there was relationship between attitude and unwanted pregnancy in adolescent and it was statistically significant. Therefore, adolescent attitudes toward sexuality affected how they would behave or respond to stimulation of sexual behavior that could lead to unwanted pregnancy.

\section{The effect of sexual behavior on unwanted pregnancy}

The result of analysis showed that there was a relationship between sexual behavior and unwanted pregnancy in adolescent.

The result of this study is consistent with a study by Pradhan et al. (2018), which stated that there wasa relationship between sexual behavior and unwanted pregnancy in adolescent and it was statisti- cally significant $(\mathrm{OR}=0.68 ; 95 \% \mathrm{CI}=0.64$ to 0.73; $\mathrm{p}<0.001)$. Adogu et al. (2014); Pringle et al. (2017), stated that sexual development was increased during adolescence period so that it can lead to sexual behavior that can also be harmful and give negative impact if it was done at an early age and without any knowledge.The risks that may occur from risky sexual behavior were the transmission of sexually transmitted diseases and unwanted pregnancies.

The conclusion of this study was that there was a positive relationship between parental role, peer role, religiosity, negative media exposure, knowledge, attitude, sexual behavior, and unwanted pregnancy.

\section{REFERENCES}

Adogu P, Udigwe I, Udigwe G, Ubajaka C (2014). Review of Problems of Adolescent Sexual Behavior and the Role of Millennium Development Goals 4, 5 and 6 in Nigeria. Adolescent and Sexual Behaviour, (August), 940948. https://doi.org/10.4236/ijcm.2014.515126.

Alabi OT, Oni OI (2017). Teenage Pregnancy in Nigeria: Causes, Effect and Control. International Journal of Academic Research in Business and Social Sciences, 7(2), 2222-6990. https://doi.org/10.6007/IJARBSS.

Aviyah E, Farid M (2014). Religiusitas, Kontrol Diri dan Kenakalan Remaja. PERSONA: Jurnal Psikologi Indonesia, 3(2), 126-129. Retrieved from http://jurnal.untag-sby.ac.id/index.php/persona/article/view/376/334.

Azinar M (2013). Perilaku Seksual Pranikah Berisiko Terhadap Kehamilan Tidak Dinginkan. Jurnal Kesehatan Masyarakat, 8(2), 153-16o. https://doi.org/10.15294/kemas.v8i2.2639.

Badan Penelitian dan Pengembangan Kesehatan. (2013). Riset Kesehatan Dasar 
(RISKESDAS) 2013. Laporan Nasional 2013, 1-384. https://doi.org/1 Desember 2013.

Cookingham LM, Ryan GL (2015). The impact of social media on the sexual and social wellness of adolescents. Journal of Pediatric and Adolescent Gynecology, 28(1), 2-5. https://doi.org/10.1016/j.jpag.2014.03.001.

Darroch JE, Woog V, Bankole A, Ashford LS (2016). Costs and Benefits of Meeting the Contraceptives Needs of Adolescents, (May 2016). Retrieved from https://www.guttmacher.org/sites/default/files/report_pdf/adding -it-up-adolescents-report.pdf

Exavery A, Kanté AM, Njozi M, Tani K, Doctor HV, Hingora A, Phillips JF. (2014). Predictors of mistimed, and unwanted pregnancies among women of childbearing age in Rufiji, Kilombero, and Ulanga districts of Tanzania. Reproductive Health, 11(1): 1-9. https://doi.org/10.1186/1742-475511-63

Haidah SM, Susan M, Bujang M, Voon Y, Chan L, Wahab AN, Kalil E, Ishak M, Kamal N (2017). The Relationship between Exposure to Sexually Explicit Material. Social Sciences \& Humanities. 25 (3): 1059 - 1072.

Landry M et al. (2017). Social Media and Sexual Behavior Among Adolescents: Is there a link?. JMIR Public Health and Surveillance, 3(2): e28. doi: 10.2196/publichealth.7149.

Mumah J, Kabiru CW, Izugbara C, Mukiira C (2014). Coping with Unintended Pregnancies: Narratives from Adolescents in Nairobi's Slums. STEP UP Research Report, (April). Retrieved from http://www.popcouncil.org/uploads/pdfs/2014STEPUP_APHRCResearchReport.pdf.
Pringle J, Mills KL, Mcateer J, Jepson R, Hogg E, Anand N (2017). The physiology of adolescent sexual behaviour: A systematic review. Cogent Social Sciences, 56(1), 1-14. https://doi.org/10.1080/23311886.2017.1368858.

Pradhan R, Wynter K, Fisher J (2018). Factors Associated with Pregnancy among Married Adolescents in Nepal: Secondary Analysis of the National Demographic and Health Surveys from 2001 to 2011. doi: 10.3390/ijerph15020229.

Pranata S, Sadeo S (2012). Kejadian Keguguran, Kehamilan yang Tidak Direncanakan dan Pengguguran di Indonesia. Penelitian Sistem Kesehatan, 15, 180-192. Retrieved from http://ejournal.litbang.depkes.go.id/index.php/hsr/article/view/2992

Ramadani $\mathrm{M}$ et al. (2014). Peran Tenaga Kesehatan dan Keluarga dalam Kehamilan Usia Remaja Roles of Health Worker and Family in Teenage Pregnancy. (94): 87-92.

Reza IF (2013). Hubungan antara religiusitas dengan moralitas pada remaja di Madrasah Aliyah (MA). Jurnal Humanitas, X(2), 45-58.

Saptarini I, Suparmi S (2016). Determinan Kehamilan Tidak Diinginkan Di Indonesia (Analisis Data Sekunder Riskesdas 2013). Jurnal Kesehatan Reproduksi, 7(1). https://doi.org/10.22435/kespro.v7i1.5096.15-24.

UNICEF. (2016). Adolescents: overview. In: UNICEF data: monitoring the situation of children and women. New York (NY): United Nations Children's Fund. https://data.unicef.org/topic/adolescents/overview/ Diakses 24 November 2017, pukul 11.56 WIB

Woog V, Kagesten A (2017). The Sexual and Reproductive Health Needs of Very Young Adolescents In Developing 
Journal of Maternal and Child Health (2018), 3(3): 216-224

https://doi.org/10.26911/thejmch.2018.03.03.06

Countries. Guttmarcher Institute, (May). Retrieved from https://www.guttmacher.org/fact-sheet/srh-needsvery-young-adolescents-indeveloping-countries.

World Health Organitation. (2016). WHO releases new fact sheets on adolescent contraceptive use. Geneva: WHO http://www.who.int/reproductiveheal th/topics/adolescence/contraceptiveuse/en/ Diakses 13 Desember 2017 Pukul 17.44 WIB

(2017). More than 1.2 million adolescents die every year, nearly all preventable. Geneva: WHO http://- www.who.int/mediacentre/news/releases/2017/yearly-adolescent-deaths/en/ Diakses 13 Desember 2017 Pukul 18.03 WIB.

(2017). HRP Annual report 2016. Geneva: WHO http://apps.who.int/iris/bitstream/10665/255768/1/WH O-RHR-HRP-17.06-eng.pdf?ua=1 Diakses 14 Desember 2017. (2018). Adolescent pregnancy. Geneva: WHO http://www.who.int/mediacentre/factsheets/fs364/en/ Diakses 13 Desember 2017. 